Article

\title{
Dependence of PV Module Temperature on Incident Time-Dependent Solar Spectrum
}

\author{
Joseph Appelbaum *(D) and Tamir Maor \\ School of Electrical Engineering, Tel Aviv University, Tel Aviv 69978, Israel; maorxtm@gmail.com \\ * Correspondence: appel@eng.tau.ac.il
}

Received: 4 January 2020; Accepted: 27 January 2020; Published: 31 January 2020

\begin{abstract}
The operating temperature of photovoltaic (PV) modules affects the photovoltaic conversion process. The operating temperature depends on various environmental conditions and on material-dependent properties of the PV modules. Many expressions for the operating temperature have been proposed in the literatures, some are simplified working Equation as NOCT (Nominal Operating Cell Temperature), and others are more complex, being based on a combination of the energy balance Equation and NOCT. The present study offers a new approach (model) for determining the PV module temperature based on the energy balance Equation and on the solar spectrum irradiance. While using the new model, the operating temperature has been determined for four module technologies: c-Si, a-Si/ $\mu \mathrm{c}-\mathrm{Si}, \mathrm{CdTe}$, and CIGS and it shows that the operating temperatures for the different cell types are close to the manufacturers' NOCT data-sheet temperatures. For c-Si technology, for example, the simulation resulted in $43.2^{\circ}$ and $46^{\circ}$ for the spectrum and NOCT models, respectively. The proposed new model offers a new approach for determining the operating temperature of PV modules.
\end{abstract}

Keywords: PV module temperature; solar spectrum; energy balance Equation; Nominal Operating Cell Temperature; SPECTRAL(2)

\section{Introduction}

The operating temperature of photovoltaic $(\mathrm{PV})$ modules plays an important role in the photovoltaic conversion process and, hence, on the energy assessment and on the economics of PV systems. The operating temperature depends on various environmental conditions, such as: the solar irradiance and its spectrum; the ambient temperature and wind speed; on material-dependent properties of the PV modules (cell technology, encapsulation, back-sheet material); properties needed for the calculation of the radiation heat transfer as albedo, sky temperature; and, on installation factors of the collector deployment in the PV field. Many expressions for the operating temperature have been proposed in the literatures, some are simplified working Equation as NOCT (Nominal Operating Cell Temperature), others are based on energy balance Equations, and many more on combinations of the energy balance Equation and NOCT model [1-8]. Expressions for the operating temperature of the PV modules are either explicit forms directly giving the temperature or are implicit forms involving variables, which themselves depend on the temperature [3,7]. The various models may be grouped into three types [4]: (a) constant temperature models (standard test condition (STC), NOCT), (b) physical based-models (such as I-V characteristics parameters, material band-gap, etc., and (c) statistical models (mathematical Equations derived from physical model; fitting coefficients to measured tested data and artificial intelligent methods). Therefore, it is expected to arrive to different operating temperatures of the PV module, also depending on the method used. The simulation of module temperature based on NOCT model is widely used, as it is simple and easy to apply and manufacturers usually include NOCT in the module characteristic data. 
The incident solar energy that is absorbed by the module is converted to electrical and thermal energies of which partly is dissipated to the external surrounding. This leads to the use of an energy balance Equation for formulating the operating temperature of the module and it further leads to a combined energy balance and NOCT model. The energy balance Equation and the combined energy and NOCT models consider the broadband irradiance and not the time-dependent solar spectrum. The proposed novel approach of the present study to determine the operating module temperature is based on a combination of the energy balance Equation and the time-dependent solar spectrum. This study calculates the operating temperature for four module technologies (c-Si, a-Si/ $\mu \mathrm{c}-\mathrm{Si}, \mathrm{CdTe}$, and CIGS for a site in the Israel desert) based on the proposed method and shows that the operating temperatures of the different cell types are close to the manufacturers' NOCT temperatures.

\section{NOCT (Nominal Operating Cell Temperature)-Based Module Temperature}

The module operating temperature that is based on normal operating cell temperature (NOCT) is commonly used $[9,10]$.

The NOCT Equation is given by:

$$
T_{c}=T_{a}+(N O C T-20) \times \frac{P_{r a d}}{800}
$$

where $T_{c}$ is the module temperature in $\left({ }^{\circ} \mathrm{C}\right)$ according to the NOCT model, $T_{a}$ is the ambient temperature, and $P_{\text {rad }}$ is the solar irradiance in $W / \mathrm{m}^{2}$. The NOCT value is defined by the global $\mathrm{G}$ in-plane irradiance $800 \mathrm{~W} / \mathrm{m}^{2}$, air mass AM1.5G, ambient temperature $T_{a}=20^{\circ} \mathrm{C}$, and wind speed $V_{\text {wind }}=1 \mathrm{~m} / \mathrm{s}$ at the PV module height. It should be mentioned that NOCT represents a steady condition at open circuit temperature of the PV module, a condition not met in real module operation.

In the beginning, the use of the energy balance Equation [11] was attempted to define the module operating temperature, however it was difficult to measure a term in the thermal losses of the PV module to the surroundings (see Section 3) in the energy balance Equation and, therefore, PV manufacturers adopted the NOCT expression. This simple method generally gives satisfactory results for ground mounted PV systems, but not for roof- integrated systems [9]. The effect of the wind speed on cell temperature is given by $[10,12]$ :

$$
T_{c}\left({ }^{\circ} \mathrm{C}\right)=T_{a}+\frac{0.32}{8.91+2 \cdot V_{\text {wind }}} \cdot G
$$

where $\mathrm{G}$ in-plane irradiance in $\mathrm{W} / \mathrm{m}^{2}$.

An expression for the module temperature by a linear model including wind speed is in [13], and Ref. [14] deals with a comparative study of NOCT-based temperature by comparing three NOCT models.

\section{Energy Balance Equation}

The approach for calculating the PV module temperature, which is based on a simplified energy balance Equation, involves equating the solar radiation absorbed by the module to the electrical output and the thermal losses is mentioned in [15-17]:

$$
P_{r a d} \tau \alpha=\eta_{P V} P_{r a d}+U_{P V}\left(T_{c}-T_{a}\right)
$$

where

$P_{r a d} \tau \alpha$ is the part of beam and diffuse radiation absorbed by the PV module, $\eta_{P V} P_{\text {rad }}$ is the electrical power produced by the PV module,

$U_{P V}\left(T_{c}-T_{a}\right)$ is the thermal losses from the PV module to the surroundings: 
$\eta_{P V}$ is the PV module efficiency given by:

$$
\eta_{P V}=\eta_{r}\left[1-\beta_{c}\left(T_{c}-T_{r}\right)\right]
$$

$\tau$ is the transmittance of the module cover (glass) for the beam and diffuse radiation, $\alpha$ is the absorption coefficient of the cells, $\eta_{r}$ is the module's efficiency at standard test condition (STC), $T_{r}$ is the reference temperature $25^{\circ} \mathrm{C}$, and $\beta_{c}$ is the power temperature coefficient of the PV cell dependent on the cell technology. Substituting Equation (4) into Equation (3) we get

$$
T_{c}=\frac{U_{P V} T_{a}+P_{r a d} \tau \alpha-P_{r a d}\left(\eta_{r}+\eta_{r} \beta_{c} T_{r}\right)}{U_{P V}-\eta_{r} \beta_{c} P_{r a d}}
$$

The thermal coefficient losses, in $W^{0} \cdot C^{-1} \cdot m^{-2}$ (per unit of module area), from the PV module to the surroundings is given in the present study, by [18]:

$$
U_{P V}=2 \cdot\left(5.67+3.86 \cdot V_{\text {wind }}\right) \cdot W^{0} \cdot C^{-1} \cdot m^{-2}
$$

where $V_{\text {wind }}$ is the wind speed in $\mathrm{m} / \mathrm{s}$. Other expressions are mentioned in [16].

The plane of array irradiance $P_{\text {rad }}$ in $W / m^{2}$ is measured or calculated at a given time for which the cell temperature is calculated.

\section{Proposed Spectrum Model-Combined Energy Balance Equation and Solar Spectrum Method}

The new approach of the present study to calculate the module operating temperature is based on the energy balance Equation (3) and the time-dependent solar spectrum. The irradiance $P_{\text {rad }}$ (see Equation (5)) is determined by the solar spectrum, which varies with time during the day. The irradiance $P_{\text {rad }}$ is calculated by:

$$
P_{\text {rad }}=\int P(\lambda) d \lambda
$$

and $P_{\text {rad }} \tau \alpha$ (see Equation (5)) is the part of the irradiance absorbed by the PV cell given by:

$$
P_{\text {rad }} \tau \alpha=\int P(\lambda) \cdot\left(1-R_{\text {cell }}(\lambda)\right) d \lambda
$$

The spectral reflectance coefficient of the PV cell is $R_{\text {cell }}(\lambda)$ and, therefore, $\left(1-R_{\text {cell }}(\lambda)\right)$ is the transmittance factor of the absorbed solar irradiance in the PV cell.

The solar spectrum depends on time, location, and the atmospheric condition. The global solar radiation, neglecting the ground reflected radiation, consisting of the direct beam and the diffuse components. Therefore, the solar spectrum is divided into two spectrum models, one for the direct beam radiation and the other for the diffuse radiation. The range of wavelengths of the solar incident radiation on the PV modules corresponds to the relevant range of the spectral response of the PV cells. The effect of varying spectral irradiance on the performance of solar cells is addressed in [19-21]. The impact of solar spectral irradiance on the yield of different technologies was studied for four locations in [20]. The study in [22] states that the spectrum has little effect for low gap materials between seasons, for clear skies, but not for large band gap materials. Figure 1 presents the external quantum efficiency of four module technologies, for which the present study calculates the operating temperature. Figure 1 was derived from articles [19-21] while using interpolations to match the sampling points to specx points needed for the spectral model SPECTRAL(2), (see below). 


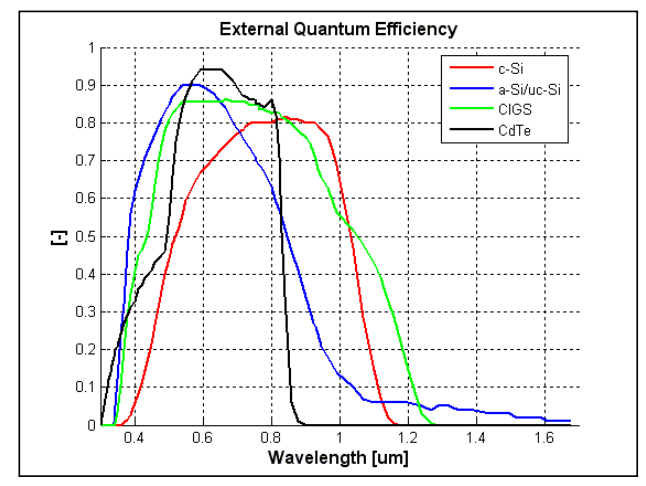

Figure 1. External quantum efficiency of four module technologies.

Several solar spectrum models were developed with time for clear skies, among them: LOWTRAN(2) [23], SPECTRAL(2) [24], SMARTS(2) [25], and REST(2) [26]. Some models present high spectral resolutions, however they require complex calculations. In the present article, the SPECTRAL(2) is used, because it conveniently fits in the computation program and is of sufficient spectral resolution. In addition, SPECTRAL(2) is listed in (http://rredc.nrel.gov/solar/pubs/spectral/model), including parameters that are needed for the solar spectrum calculation (see also [27]), mentioning the advantage of SPECTRAL(2) on SMARTS(2)). SPECTRAL(2) was implemented by a single function and interfaced as described in Table 1 . The parameters 1, 2, 3, 8 and 9 are easily obtainable, whereas the atmospheric data for the parameters 4-7 may be obtained for locations worldwide (http://aeronet.gsfc.nasa.gov). The output of spectral model is:

Table 1. SPECTRAL(2) interface.

\begin{tabular}{ll}
\hline \multicolumn{1}{c}{ I/O } & \multicolumn{1}{c}{ Description/Comments } \\
\hline 1. longitude (deg.) & East positive \\
2. latitude (deg.) & North positive \\
3. altitude (m) & Above sea level \\
4. alpha $(-)$ & Angstrom exponent $(440-870 \mathrm{~nm})$ \\
5. tau500 $(-)$ & Aerosol optical depth at $500 \mathrm{~nm}$ \\
6. watvap $(\mathrm{cm})$ & water vapor precipitation \\
7. ozone $(\mathrm{atm} . / \mathrm{cm})$ & ozone amount \\
8. zenref $(\mathrm{deg})$. & Zenith angle \\
9. daynum $(-)$ & Day number $(1-$ Jan.1st) \\
Output & Spectral wavelength $(0.3-1.7)$ \\
1. specx $(\mu m)$ & direct power spectrum at surface \\
2. specdir $\left[\frac{\mathrm{mW}}{\mathrm{m}^{2} \cdot n m}\right]$ & normal to beam \\
3. specdif $\left[\frac{\mathrm{mW}}{\mathrm{m}^{2} \cdot n m}\right]$ & diffuse power spectrum at \\
\hline
\end{tabular}

specx-sampling points along the spectrum axis, dense for shorter waves and sparse for longer waves.

specdir-direct beam solar irradiance (normal to solar rays).

specdir-diffuse irradiance on horizontal plane.

Two locations in Israel were chosen to demonstrate the solar spectrum for a given day and an hour-Sde Boker, $30.67^{\circ} \mathrm{N}$ (the desert) on February 1 at 16:00, and Eilat $29.55^{\circ} \mathrm{N}$ on August 4 at 12:00 noon. Table 2 contains the parameters for producing the solar spectrum at Sde Boker and Eilat. Figure 2 shows the results. A remark on the irradiances is in order. The direct beam irradiance is 
normal to the solar rays, whereas the diffuse irradiance is on a horizontal plane. Therefore, the global irradiances on a horizontal plane is given by:

$$
\text { Global }_{\text {irrad }}=\text { Direct }_{\text {irrad }} \times \cos (\text { zenith angle })+\text { Diffuse }_{\text {irrad }}
$$

Table 2. Data for obtaining the solar spectrum.

\begin{tabular}{lcc}
\hline \multicolumn{1}{c}{ Inputs } & $\begin{array}{c}\text { Sde Boker } \\
\text { Feb 1, 16:00 }\end{array}$ & $\begin{array}{c}\text { Eilat } \\
\text { Aug 4, 12:00 }\end{array}$ \\
\hline 1. longitude (deg.) & 34.8 & 34.9 \\
2. latitude (deg.) & 30.9 & 29.5 \\
3. altitude (m) & 480 & 15 \\
4. alpha (-) & 2.17 & 1.4 \\
5. tau500 (-) & 0.084 & 0.209 \\
6. watvap (cm) & 0.85 & 2.4 \\
7. ozone & 0.257 & 0.279 \\
\hline
\end{tabular}
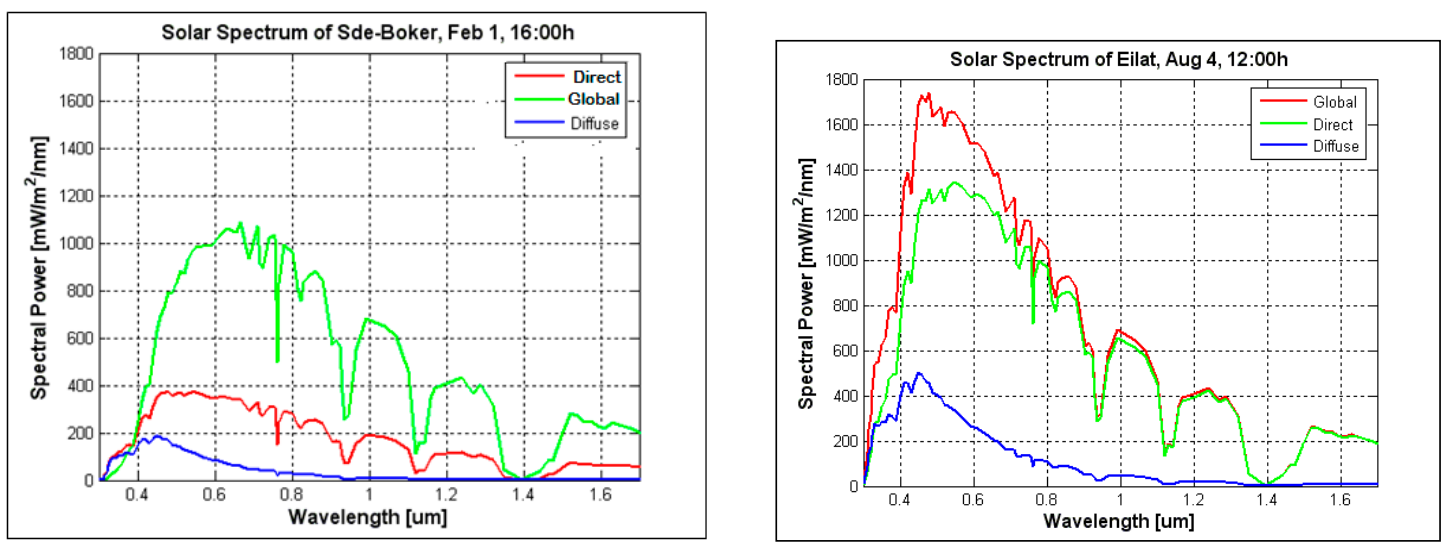

Figure 2. Spectrum at Sde Boker and Eilat-global, direct, diffuse.

\section{Photovoltaic (PV) Module Temperature-Simulation Results}

This section deals with the calculation of the operating temperature $T_{c}^{s p e c}\left({ }^{\circ} \mathrm{C}\right)$ for four different PV module technologies that are based on the solar spectrum model, as in Equations (5) and (7). The integration limits of the spectrum correspond to the spectral response of each technology. Table 3 lists the details. The transmittance factors $\left(1-R_{\text {cell }}(\lambda)\right)$ of the absorbed solar irradiance in the PV cells (see Equation (8)) are shown in Figure 3 for the four types of the modules that were derived from articles in $[28,29]$ while using interpolations to match specx points for SPECTRAL(2).

Table 3. Module type and manufacturer.

\begin{tabular}{|c|c|c|c|c|c|}
\hline Module & Technology & $\beta_{c}\left(\% /{ }^{\circ} C\right)$ & $\begin{array}{l}T_{c}^{\text {spec }} \\
\left({ }^{\circ} \mathrm{C}\right)\end{array}$ & $\begin{array}{c}\text { NOCT } \\
\left({ }^{\circ} \mathrm{C}\right)\end{array}$ & $\begin{array}{c}\text { NOCT }-T_{c}^{\text {spec }} \\
\left({ }^{\circ} \mathrm{C}\right)\end{array}$ \\
\hline SCHOTT MONO & c-Si & -0.44 & 43.2 & 46 & 2.8 \\
\hline SCHOTT ASI"M 100 & $\mathrm{a}-\mathrm{Si} / \mu \mathrm{c}-\mathrm{Si}$ & -0.20 & 44.6 & 49 & 4.4 \\
\hline FirstSolarFS-280 Series $2^{\mathrm{TM}}$ & $\mathrm{CdTe}$ & -0.25 & 43.6 & 45 & 1.4 \\
\hline Wurth Solar GeneCIS 80 & CIGS & -0.36 & 45.2 & 47 & 1.8 \\
\hline
\end{tabular}




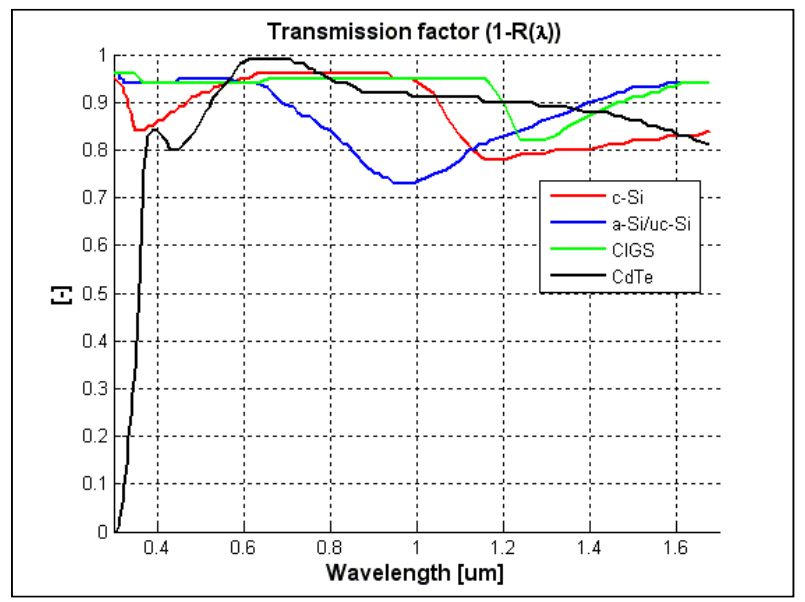

Figure 3. Transmittance factors.

The calculated module temperatures $T_{c}^{\text {spec }}\left({ }^{\circ} \mathrm{C}\right)$ in Table 3 are average maximum values based on the solar spectrum model at Sde-Boker site. The results pertain to module inclination angle $25^{\circ}$ facing due south, calculated for noontime (at 12:00) for each day for the period of six months and for an average ambient temperature $29.7^{\circ} \mathrm{C}$ at the location. Table 3 also includes the NOCT temperature (specified by the manufacturers) for the four PV module technologies. The $T_{c}^{\text {spec }}\left({ }^{\circ} \mathrm{C}\right)$ in Table 3 was calculated at 12:00, as the module temperature is expected to be the highest since in the morning and in the afternoon hours the solar irradiance is lower as well the ambient temperature. The solar spectrum in the morning and afternoon is usually different than at noon, however the lower ambient temperature might affect the module temperature more than the difference in the spectrum. Table 3 also shows that the difference in the module temperature based on $T_{c}^{\text {spec }}\left({ }^{\circ} \mathrm{C}\right)$ model and NOCT is $2.8^{\circ}, 4.4^{\circ}, 1.4^{\circ}, 1.8^{\circ}\left({ }^{\circ} \mathrm{C}\right)$ for $\mathrm{c}-\mathrm{Si}, \mathrm{a}-\mathrm{Si} / \mu \mathrm{c}-\mathrm{Si}, \mathrm{CdTe}$, and CIGS technologies, respectively.

Simulation results of the operating temperature for c-Si module are shown in Figure 4 based on the spectrum model and NOCT for 21st of each month for the period from December to June. Differences in the operating temperature are apparent for module temperature above 30 degrees.

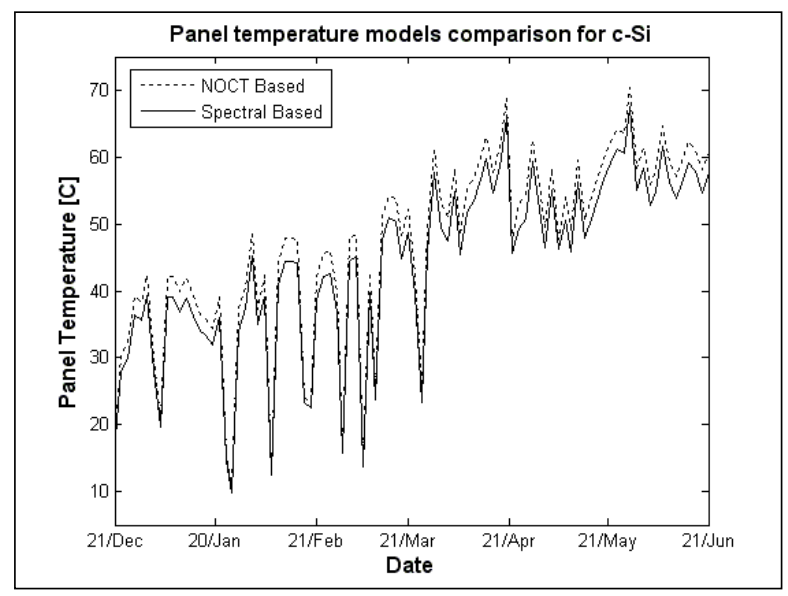

Figure 4. Variation of c-Si module temperature at noon on the 21st of month, Dec.-June.

\section{Discussion}

PV system losses due to the operating temperature of PV modules are the main loss component and they may constitute more than 10 percent $[30,31]$, therefore the operating temperature plays an important role in the energy assessment and in the economics of PV systems. Numerous expressions were developed for the operating temperature involving environmental variables and numerical 
parameters, which are material and system dependent. Therefore, one must be careful in applying a particular expression for the operating temperature of the PV module, because the expressions have been developed for particular deployments of the PV system. For that reason, one cannot compare the methods and results of the operating temperature for different types of PV systems and at different locations. The simulation results for the operating temperature that are obtained by the proposed spectrum model at the specific location where the study pertains are close to the manufacturers' NOCT temperatures, thus verifying, by simulation, the validity of the new spectrum approach. Still, the new approach justifies further studies.

\section{Conclusions}

Many expressions for the operating temperature have been proposed in the literatures, some are based on NOCT and others are more complex and are based on the energy balance Equation. The novel approach of the present study for determining the operating module temperature is based on a combination of the energy balance Equation and on the spectral distribution of the solar irradiance. SPECTRAL(2) was used to generate the solar spectrum. The operating temperature of the PV module $T_{c}^{\text {spec }}\left({ }^{\circ} \mathrm{C}\right)$ was calculated for four module technologies: c-Si, a-Si/ $\mu \mathrm{c}-\mathrm{Si}, \mathrm{CdTe}$, and CIGS for a site in the Israel desert and shows that the operating temperatures are close to the manufacturers' NOCT temperatures. No experimental validation has been performed on the new model. Yet, the proposed model indicates a different and a promising approach that justifies further studies.

Author Contributions: J.A. and T.M. conceived the new model for the operating temperature of the PV module, J.A. wrote the paper. All authors have read and agreed to the published version of the manuscript.

Conflicts of Interest: The authors declare no conflict of interest.

\section{References}

1. Armstrong, S.; Hurley, W.G. A thermal model for photovoltaic panels under varying atmospheric conditions. Appl. Therm. Eng. 2010, 30, 1488-1495. [CrossRef]

2. Koehl, M.; Heck, M.; Weismeier, S. Wirth, Modeling of the nominal operating temperature based on outdoor weathering J. Sol. Energy Mater. Sol. Cells 2011, 95, 1638-1646.

3. Skoplaki, E.; Palyvos, J.A. Operating temperature of photovoltaic modules: A survey of pertinent correlations. Renew. Energy 2009, 34, 23-29. [CrossRef]

4. Liao, W.; Heo, Y.; Xu, S. Evaluation of temperature dependent models for OV yield prediction. In Proceedings of the 4th Building Simulation and Optimization Conference, Cambridge, UK, 11-12 September 2018.

5. Aoun, N. Outdoor testing of free standing PV module temperature under desert climate. Int. J. Ambient Energy 2019. [CrossRef]

6. Ciulla, G.; Brano, V.I.; Moreci, E. Forcasting the cell temperature of PV module with an adaptive system. Int. J. Photoenergy 2013. [CrossRef]

7. Dubey, S.; Sarvaiya, J.N.; Seshardi, B. Temperature dependent photovoltaic (PV) efficiency and its effect on PV production in the world- a review. Energy Procedia 2013, 33, 311-321. [CrossRef]

8. Brano, V.L.; Ciulla, G.; Franzitta, V.; Viola, A. A novel implicit correlation for the operative temperature of a PV panel. AASRI Procedia 2012, 2, 112-120. [CrossRef]

9. Alonso Garcia, M.C.; Balenzategui, J.L. Estimation of photovoltaic module yearly calculations. Renew. Energy 2004, 29, 1997-2010. [CrossRef]

10. Migan, G.A. Study of the Operating Temperature of a PV Module; Project Report 2013 MVK160 Heat and Mass Transfer; Lund University, Faculty of Engineering: Lund, Sweden, 2013.

11. How HOMER Calculates the PV Cell Temperature. Available online: https://www.homerenergy.com/ products/pro/docs/latest/how_homer_calculates_the_pv_cell_temperature.html (accessed on 1 January 2020).

12. Wenham, M.A.; Green, M.A.; Watt, M.E.; Corkish, R. Applied Photovoltaics, 2nd ed.; UNSW. Centre for photovoltaic Engineering: Sydney, Australia, 2006.

13. Muzathik, A.M. Photovoltaic module operating temperature estimation using a simple correlation. Int. J. Energy Eng. 2014, 4, 151-158. 
14. Umoette, A.T.; Ubom, E.A.; Akpan, I.E. Comparative analysis of three NOCT cell temperature models. Int. J. Syst. Sci. Appl. Math. 2016, 1, 69-75.

15. Evans, D.L. Simplified method for predicting photovoltaic array output. Sol. Energy 1981, 27, 555-560. [CrossRef]

16. Mattei, M.; Notton, G.; Cristofari, C.; Muselli, M.; Poggi, P. Calculation of the polycrystalline PV module temperature using a simple method of energy balance. Renew. Energy 2006, 31, 553-567. [CrossRef]

17. Neises, T.W.; Klein, S.A.; Reindl, D.A. Development of a thermal model for photovoltaics modules and analysis of NOCT Guidelines. J. Sol. Energy Eng. 2011, 134. [CrossRef]

18. Duffie, J.A.; Beckman, W.A. Solar Engineering of Thermal Processes; Wiley: London, UK, 1991; ISBN 978-0-471-51056-7.

19. Prentice, J.S.C. Spectral response of a-Si:H p-i-n solar cells. Sol. Energy Mater. Sol. Cells 2001, 69, 303-314. [CrossRef]

20. Nann, S.; Emery, K. Spectral effects on PV-device rating. Sol. Energy Mater. Sol. Cells 1992, 27, $189-216$. [CrossRef]

21. Dirnberger, D.; Blackburn, G.; Muller, B.; Reise, C. On the impact of solar spectral irradiance on the yield of different PV technologies. Sol. Energy Mater. Sol. Cells 2015, 132, 431-442. [CrossRef]

22. Eke, R.; Betts, T.R.; Gottschalg, R. Spectral irradiance effect on the outdoor performance of photovoltaic modules. Renew. Sustain. Energy Rev. 2017, 69, 429-434. [CrossRef]

23. McClatchey, R.A.; Selby, J.E. Atmospheric Transmittance from 0.25 to $28.5 \mathrm{~lm}$ : Computer Code LOWTRAN2; AFCRL-72-0745, Environ. Res. Paper No. 427; Airforce Cambridge Research Laboratories: Wright-Patterson Air Force Base, OH, USA, 1972.

24. Bird, R.E. A simple, solar spectral model for direct-normal and diffuse horizontal irradiance. Sol. Energy 1984, 32, 461-471. [CrossRef]

25. Gueymard, C.A. SMARTS2, a Simple Model. of the Atmospheric Radiative Transfer of Sunshine: Algorithms and Performance Assessment; FSEC-PF-270-95; Florida Solar Energy Center: Cocoa, FL, USA, 1995.

26. Gueymard, C.A. REST2, High-performance solar radiation model for cloudless-sky irradiance, illuminance, and photosynthetically active radiation-Validation with a benchmark dataset. Sol. Energy 2008, 82, 272-285. [CrossRef]

27. Utrillas, M.P.; Boscá, J.V.; Martínez-Lozano, J.A.; Cañada, J.; Tena, F.; Pinazo, J.M. A comparative study of SPCTRAL2 and SMARTS2 parameterized models based on spectral irradiance measurements at Valencia, Spain. Sol. Energy 1998, 63, 161-171. [CrossRef]

28. Santbergen, R.; van Zolingen, R.J.C. The absorption factor of crystalline silicon PV cells: A numerical and experimental study. Sol. Energy Mater. Sol. Cells 2008, 92, 432-444. [CrossRef]

29. Santbergen, R.; Goud, J.M.; Zeman, M.; van Roosmalen, J.A.M.; van Zolingen, R.J.C. The AM1.5 absorption factor of thin-film solar cells. Sol. Energy Mater. Sol. Cells 2010, 94, 715-723. [CrossRef]

30. Kumar, N.M.; Kumar, M.R.; Rejoice, P.R.; Mathew, M. Performance analysis of $100 \mathrm{~kW}_{\mathrm{p}}$ grid connected Si-poly photovoltaic system using PVsyst simulation TOOL. Energy Procedia 2017, 117, 180-189. [CrossRef]

31. Barua, S.; Prasath, R.A.; Boruah, D. Rooftop solar photovoltaic system design and assessment for the academic campus using PVsys software. Int. J. Electr. Eng. 2017, 5, 76-83.

(C) 2020 by the authors. Licensee MDPI, Basel, Switzerland. This article is an open access article distributed under the terms and conditions of the Creative Commons Attribution (CC BY) license (http://creativecommons.org/licenses/by/4.0/). 